\title{
Dramatization as method in political theory
}

\author{
Iain Mackenzie ${ }^{\mathrm{a}, *}$ and Robert Porter ${ }^{\mathrm{b}}$ \\ ${ }^{a}$ Department of Politics and International Relations, University of Kent, Canterbury, \\ CT2 7NX, UK. \\ i.mackenzie@kent.ac.uk \\ ${ }^{\mathrm{b}}$ The Centre for Media Research, University of Ulster, Coleraine BT52 1SA, Northern Ireland. \\ r.porter@ulster.ac.uk \\ *Corresponding author.
}

\begin{abstract}
The aim of this article is to give an account of a methodological link between drama and political theory. This account is drawn primarily from the early philosophical work of Deleuze. Following Deleuze, we will refer to it as the method of dramatization'. We will argue that dramatization is a method aimed at determining the quality of political concepts by 'bringing them to life', in the way that dramatic performances bring to life the characters and themes of a playscript. We demonstrate that this can be specified in relation to the development of this method in Deleuze's early philosophical work as a practical, critical and artistic method and, in relation to the ontological assumptions he articulated and defended in Difference and Repetition, as a process of intensification of the Idea of the political. By way of example, we discuss how the dramatization of the concept of ideology functions in Deleuze and Guattari's Anti-Oedipus and $A$ Thousand Plateaus. We conclude with some lines of inquiry that could be pursued by political theorists looking to investigate further the dramatic nature of method in political theory.
\end{abstract}

Contemporary Political Theory (2011) 10, 482-501. doi:10.1057/cpt.2010.38;

published online 19 July 2011

Keywords: dramatization; Deleuze; method; political theory

Although certainly not a common-place in all quarters, it is nonetheless fair to say that contemporary political theorists, of various stripes, are becoming increasingly interested in aesthetics (for example, Virilio, 2003; Rancière, 2004; Grosz, 2008). Not coincidentally, we are also witnessing a growing interest in the explicitly political analysis of a broad range of particular artistic forms and experiences (for example, Shapiro, 1999; Debrix and Weber, 2003; Lisle, 2009). One of the arts showing a recent surge in this respect is drama. While

(C) 2011 Macmillan Publishers Ltd. 1470-8914 Contemporary Political Theory Vol. 10, 4, 482-501 www.palgrave-journals.com/cpt/ 
play-scripts and productions have long been poured over by literary scholars with an eye for the political meanings contained within them, political theorists are turning their attention to this art form in order to examine its effects within the political domain: for example, the ways in which civic life is staged as part of the theatrical experience (Finlayson and Frazer, 2009). In this article we aim to contribute to these discussions by excavating, and elaborating upon, an account of a methodological link between drama and political theory. This account is drawn primarily from the early philosophical work of Deleuze. ${ }^{1}$ Following Deleuze, we will refer to this method as 'dramatization' (Deleuze, 2004). We will argue that dramatization is a method aimed at determining the dynamic nature of political concepts by 'bringing them to life', in the way that dramatic performances can bring to life the characters and themes of a playscript. What this means, beyond the merely analogous, will be clarified below. In the course of this discussion, we will lend our support to the view that political theory must engage positively with general theoretical aesthetics and the political implications of particular artistic forms. If methodological work in political theory is understood, generally, as reflection upon how to 'access' the political, then, as we argue below, dramatization offers a compelling account of the artistic nature of such work.

The idea that drama can serve as a medium for the expression of political ideas and debates is virtually co-extensive with the history of drama itself: from the early Greek plays to the recent theatrical re-enactments of politically charged public inquiries. Equally, the idea that political theory often contains dramatic elements and references within it is hardly contentious. For example, it has been said that Plato's Republic owes a 'debt to Aristophanic comedy' (Pappas, 2003, p. 14). There is also the growing recognition of the significance (Skinner, 2008) of Chapter 16 of Hobbes's Leviathan, entitled 'Of persons, authors and things personated', which contains important distinctions between persons, artificial persons and those artificial persons who 'have their words and actions owned by those whom they represent', whom Hobbes calls 'actors' (1968, p. 218). In a general sense, moreover, we are familiar with the political theorist as a kind of director, staging a situation for the reader that presents a dramatic version of the problem being addressed: from examples about 'desert islands' to Rawls's inventive staging of the original position in A Theory of Justice (1972).

That said, it is clear that most political theory that employs dramatic elements does so without making any claim to the methodological importance of dramatization, viewing it instead as a simple heuristic or analogical device in the service of more traditional, interpretive and normative methods. Our aim is to show that a solid methodological case, based on a set of rigorous ontological assumptions, can be articulated to make explicit that which political theorists often implicitly enact in their writing: the dramatization of political concepts. 
Between drama as a medium for political discussion and political-theoretical uses of dramatic elements and motifs, there is a methodological ground that Deleuze established in his early philosophical work. It is this ground that we will survey with a view to instigating debate and discussion about the methodological relation between political theory and drama.

The article is divided into three parts. In part one, we introduce 'dramatization as method' by tracing its emergence in Deleuze's early works in the history of philosophy - his books on Hume, Bergson and Kant, respectively (Deleuze, 1984, 1988, 1991) - before addressing its explicit articulation in both Nietzsche and Philosophy (Deleuze, 1983) and Difference and Repetition (Deleuze, 1994). In doing so, we will outline some of the key philosophical claims that underpin the method of dramatization. It will be shown that dramatization has its roots in a practical, critical and artistic approach to the determination of concepts and that it then developed into an explicit methodological procedure guided by a post-Kantian understanding of the role played by ideas in thinking.

Having traced the emergence of this method in Deleuze, in part two we will ask what exactly is meant by claiming that dramatization is a way of 'bringing concepts to life'? We will argue that dramatization enables the (political) philosopher to determine the conditions that give concepts their quality and force (for instance, what makes them persistent or fleeting, powerful or impotent, demanding or pointless and so on). This is important because it provides access to, what Deleuze calls, 'Ideas'. ${ }^{2}$ However, to understand what Deleuze meant by an Idea, and how Ideas are expressed through concepts, one must stride into the metaphysical heartlands of his philosophy of difference. Much of part two, therefore, will involve an overview of this metaphysical terrain; in particular, the two-fold account of the real as virtual and actual, and his novel theorization of the event as a change of intensity. In this way, we will be able to articulate the principal ontological commitments that sustain the method of dramatization.

In the third part, we consider how this encounter with Deleuzean metaphysics impacts upon political theory. To put it bluntly, what kind of critical purchase does the method of dramatization actually give us in trying to determine the conditions of political concepts? This is not a question that can be answered in full. In this article, therefore, we will restrict our answer to this question to an analysis of how Deleuze and Guattari, in their most obviously political-philosophical texts, practice the dramatization of political concepts in ways that express the Idea of the political. In particular, we will examine their use of 'ideology' in both Anti-Oedipus (Deleuze and Guattari, 1984) and A Thousand Plateaus (Deleuze and Guattari, 1988). It will be argued that 'ideology' functions as a slogan in these texts, a slogan that is intended to dramatize both this hackneyed political concept (bring it back to life, so to speak) and the potential for continual variation within the political domain 
that such sloganeering implies (concepts can always be declared 'dead' and/or 'brought back to life'). To use political concepts in this dramatic way, in other words, is to presuppose that political theory is a practical and critical engagement with the Idea of the political.

By way of conclusion, we venture some brief remarks on what this foray into Deleuzean method might mean for interpretive and critical practices within political theory, generally speaking, with a view to setting the agenda for future work on dramatization as method in political theory.

\section{The Emergence of Dramatization as Method in Deleuze}

Deleuze's (1991) early work on Hume, particularly Empiricism and Subjectivity, is characterized by a desire to resist the rationalist view that concepts express essences and that one can only understand the relation between concepts when one has first understood their respective essences. As clarified by Hayden, Humean empiricism for Deleuze is 'a theory of relations' that 'displaces the emphasis on essential characteristics and stresses instead that relations come into existence by practical rather than essential or necessary means' (Hayden, 1995, p. 302). If we add to this, as Deleuze does, the claim that concepts are intrinsically relational, then we have the basis for an empiricist displacement of the rationalist approach to the determination of concepts. That is, if all concepts express relations (in the double sense that they group elements together under the concept and that they always exist in relation to other concepts) and there is no rational necessity for the relations they express, then the determination of concepts must itself be a practical activity (rather than a merely theoretical activity aimed at unearthing the essential characteristics of the related elements). Of course, this does not specify the kind of practical activity involved in the determination of concepts. Indeed, one could follow Deleuze in many divergent directions from this opening empiricist claim. In our view, however, and with a view to the methodological implications of this position, an important connection can be made to an under-theorized aspect of Deleuze's work on Bergson.

We find in Deleuze's (1988) treatment of Bergson that this practical engagement can take surprising forms. For example, he follows Bergson (2004) in drawing our attention to the ways in which comedy can determine the conditions of thought through dramatizing concepts such as the 'moral law'. In the following passage, for instance, Deleuze lays out the possibility of irony and humour as forms of repetition that function in this way. He writes;

There are two known ways to overturn moral law. One is by ascending towards the principles: challenging the law as secondary, derived, 
borrowed ...; denouncing it as involving a second-hand principle which diverts an original force or usurps an original power. The other way, by contrast, is to overturn the law by descending towards the consequences, to which one submits with a too-perfect attention to detail. By adopting the law, a falsely submissive soul manages to evade it and to taste pleasures it was supposed to forbid. We can see this in demonstration by absurdity and working to rule, but also in forms of masochistic behaviour which mock by submission. The first way of overturning the law is ironic, where irony appears as an art of principles, of ascent towards the principles and of overturning principles. The second is humour, which is an art of consequences and descents, of suspensions and falls ... . Repetition belongs to humour and irony; it is by nature transgression or exception .... (Deleuze, 1994, p. 5)

Where irony plays with the forces and powers that give shape to the moral law, forces and powers that can be used to ridicule and usurp the tendency to speak about it in rather lofty terms, humour implies descent to its consequences, an excessive literalism that dramatizes the contingency and absurdity of this concept. Both approaches privilege the relations expressed by the concept of the moral law and express those relations by drawing them out through a practical engagement with those relations themselves. The example is especially pertinent to our discussion because it shows that practical philosophical engagement can take the form of an artistic engagement; in this case the art of the comic. With a nod back to Plato's debt to Aristophanes, comedy can function as a form of dramatization that practically expresses the relations that determine concepts and, as such, it can function as a properly methodological practice. ${ }^{3}$

We can clarify and generalize what is at stake in this practical engagement with concepts if we consider how it was further developed in Deleuze's (1984) work on Kant. It is well-known that his book on Kant was 'a book on an enemy', but it is also becoming increasingly clear that Deleuze was deeply indebted to his enemy; in particular, to the extent that Deleuze articulated his theory of Ideas as a realization of Kant's critical project (Kerslake, 2002, 2009; Smith, 2006; McMahon, 2009). Deleuze can be characterized as a postKantian, in these two important respects: (a) that things in themselves are not self-determining and as such philosophy's task is not to find the concepts that represent the self-determining nature of things (in this sense he is at one with the Kantian critical turn against dogmatism); (b) that ideas are necessarily indeterminate but nonetheless serve a practical role vis-à-vis concept formation. Deleuze criticizes Kant's 'Copernican turn', however, because in situating ideas in the remote reaches of our faculty of rational representation Kant claims that they cannot be the object of any possible experience. It is not that 
Deleuze argues that we can simply experience ideas in their indeterminacy (that would be to create a dogmatism of the Idea), but that the indeterminacy of Ideas is a constant problem for our experience of the world. The problem is this: Ideas provoke representation through conceptualization but the concepts that are produced never fully represent the Ideas they express. That is, Deleuze treats Ideas as real problems; as outside of yet productive (rather than inside and regulative) of thought. As elegantly summarized by McMahon, treating ideas as problems in this sense means that 'they confront and compel thought in virtue of their positive indeterminacy, an indeterminacy that nevertheless provokes thought to its highest powers of determination' (2009, p. 96); hence Deleuze's formal agreement with Kant that ideas have a practical role in the formation of concepts. On this account, the practical determination of concepts discussed above in relation to Hume and Bergson is accorded its full critical potential as the on-going engagement with, what we may call, 'problematic Ideas' that provoke thought. We will discuss more fully what Deleuze means by an Idea in the next section but for now we can maintain that the practical nature of determining concepts is also, for Deleuze, a thoroughly critical task, in the Kantian sense of surpassing dogmatism.

Before leaving Deleuze's treatment of Kantian critique there is one further insight that he draws from his 'enemy' that marks a crucial step towards the method of dramatization; namely, his interpretation of Kant's account of the 'aesthetic idea' (Kant, 1952). According to Deleuze, Kant recognizes that aesthetic judgements are precisely those that provoke thought by virtue of their indeterminacy; that is, they presuppose 'the existence of a free indeterminate accord' of the faculties $(1984$, p. 60). Without going into the full ramifications of this insight, it is clear that Deleuze incorporates it into his general reconstruction what it means to think in Difference in Repetition. In other words, there is a necessarily aesthetic dimension to the practical and critical elements of conceptual determination developed through his engagement with Hume, Bergson and Kant. In general, Deleuze argues that we should move from determining the conceptual parameters of ideas to exciting the Ideal yet indeterminate forces at work within concepts through a creative or artistic understanding of the task intrinsic to philosophy, namely thinking. All the pieces are now in place for Deleuze's explicit turn to the method of dramatization.

Deleuze's explicit articulation of the method of dramatization is first found in Nietzsche and Philosophy. In the three paragraphs that make up the section 'Nietzsche's Method', the method of dramatization is presented as the only one 'adequate to Nietzsche's project and to the form of the questions that he puts: a differential, typological and genealogical method' (Deleuze, 1983, p. 79). ${ }^{4}$ Moreover, addressing the possibility that bringing philosophical questions and concepts to life by creating characters appropriate to them may 
tend towards 'anthropologism', Deleuze argues that the transformations undergone by Nietzsche's characters always express forces at work that are unknown to man: 'the method of dramatization surpasses man on every side' (Deleuze, 1983, p. 79). Nietzsche's characters, according to Deleuze, must not be read as 'more-or-less' human as this de-dramatizes the Ideal forces at work by referring them back to a fixed, given, 'dead', and, in general, 'unproblematic' idea of the human. The importance of this in Deleuze's reading of Nietzsche is confirmed in his contribution to a colloquium on Nietzsche in 1964. He concludes, Nietzsche 'not only wrote a philosophy of theatre, he also brought theatre into philosophy itself. And with it, he brought new means of expression to transform philosophy' (Deleuze, 2004, p. 127). At this stage, in Deleuze's work, the method of dramatization is firmly established as that approach to Ideas, the indeterminate experience that exceeds the subject's own representations of experience, which sets them into motion through a process of intense characterization (what this intensification requires will be discussed below). Internalizing Nietzsche's philosophical dramas as the realization of Kantian critique, therefore, was a further decisive moment in the emergence of a recognizable method within his work.

The presentation of Difference and Repetition for his Doctorat d'État and the defence subsequently published under the title 'The Method of Dramatization' are the high water mark of Deleuze's appeal to this method. It is at this time that Deleuze generalizes dramatization as the method proper to a philosophy of difference. Deleuze, particularly in Difference and Repetition, conceives of the philosopher as director and the philosophical text as a script with characters and roles that the reader can and must re-enact if the force of the concepts within the text is to be redeployed. In the Kantian language that Deleuze often deploys, we can say that the experience of re-enactment forces us to determine the Idea of the script differently from what we think it is by virtue of the necessarily indeterminate nature of the script that the performance expresses (Deleuze, 1994, p. 9).

\section{The Ontological Claims}

Let us re-pose the questions rather bluntly: in what sense is dramatization a method? And, in 'bringing concepts to life', what does this method 'discover'? As established above, dramatization is a practical, critical and artistic method for the determination of concepts. The aim of this method, therefore, is an appreciation of the conditions that give concepts their force, their quality. By which we mean, the conditions that explain why certain concepts are pertinent, relevant and useful (or not) as concepts that provoke thought about the world and our place in it. But what are the ontological implications of determining

488 (C) 2011 Macmillan Publishers Ltd. 1470-8914 Contemporary Political Theory Vol. 10, 4, 482-501 
the force and quality of concepts? According to Deleuze, the task of determining concepts is important because this is the means by which we can access Ideas. An Idea is 'in itself a system of differential relations and the result of a distribution of remarkable or singular points (ideal events)' (Deleuze, 2004, p. 94). In this section we will chart the argument behind this two-fold aspect of the Idea: how do we understand the Idea as 'a system of differential relations' and as 'the result' of ideal events? We will argue that accessing the differential relations that constitute the Idea requires that this access takes the form of an event such that to know the Idea one must constitute it differently. As such, the dramatization of concepts is a method that enables access to the 'dynamic spatio-temporal determinations' (the differential relations) that constitute the terrain of the Idea and, furthermore, this method requires the creation of difference within the Idea itself in order to capture the dynamics within that terrain (the results of Ideal events). As Deleuze puts it: 'We distinguish Ideas, concepts and dramas: the role of dramas is to specify concepts by incarnating the differential relations and singularities of an Idea' (Deleuze, 1994, p. 218).

We are well aware, though, that such Deleuzean terminology is of little help if it is not connected to our everyday experiences. When we talk in more everyday terms about drama we typically have in mind a work intended for performance; 'a state, situation, or group of events involving forces in opposition to each other', as glossed by the standard dictionary definition. In this sense, to qualify something as dramatic is to claim that it has a vivid, striking, heightened, illuminating or powerful affect. As such, to dramatize is to discover the 'forces' within the novel, poem, text, painting and so on by making them vivid. Dramatization, therefore, even in common parlance is the process by which a text or situation is brought to life such that it effects a change in the emotional state of those involved (say, performers and spectators). Furthermore, in dramatizing a script, for example, we witness the creation of what we may call dramatis personae; where the characters in the text are 'brought to life' - given personae - through a complex combination of directorial, performative, contextual and other forces. There is, as is well-known within theatre studies, a form of discovery in the playing of the part; a discovery of the dynamic trajectories in which the character is implicated in the particular way that the character is performed and the play-script 'staged'. But what is being discovered in these moments of dramatization?

As Deleuze argues, it is the intensity of the character (the concept, the text and so on) that is discovered. Macbeth's monologues, for example, can be read on the page but they demand an audience, an actor, a performance space and so on if the intensity they contain is to be made apparent. Importantly, therefore, the intensity of Macbeth's monologues can only be determined through dramatization but this means that any particular expression of that intensity is always relational (there must always be an audience, for example, 
for the monologue). In this sense, dramatization as method is a method of intensification. As with the characters of a play-script so it is with the concepts of a philosophical text; in order to determine their force one must bring out their intensity by setting them within a series of conceptual, textual and performative relations, rather than by seeking to determine their essence in advance of their manifestation within that particular relational domain. As it stands, though, this rests upon the notion that the intensity we experience is always relational. Deleuze's ontological claim is more profound, however. For Deleuze, all the relations that we experience are the result of a process of intensification, and it is to this fundamental aspect of his philosophical system that we must now turn.

What is intensification? In the context of our discussion of method, intensification is the process constitutive of the extensive diversity implied by conceptualization. Although concepts group together elements that appear the same from the perspective of some criterion of identity, the point of creating the concept is to express the intensity of the elements that it groups together by bringing them into relations with each other. Clearly, this requires some explication and clarification. Returning to the play-script, for a moment, we can say that the characters are conceptualized by being grouped together in a narrative structure, for example, but it is only through performance that one is able to distil the intensity of the relationships between them that their diverse roles in the narrative are meant to express. Putting on the play, in other words, is analogous to the process of crystallization; one of Deleuze's favourite examples of intensification; and one, it is worth noting, he also makes good use of in his discussion of the 'time-image' in Cinema 2 (Deleuze, 1989, p. 68). As the crystalline solution precipitates, individual crystals are formed within the soluble field of potentials (potential individuals). The actual (extensive) crystals are therefore the result of a process of individuation from within a solution defined by the potential for different individuations - that is, the crystalline solution itself must be understood as a distribution of different potentials. Here, the solution is the Idea (or the intense relationships that the script expresses), the individual crystals are the elements (the actual relationships between the characters) that emerge in the process of crystallization that determine how the solution can be conceptualized (the dramatization of the script that establishes a series of relationships between these performers of this play in this particular context). ${ }^{5}$ Where concepts group together actual things, Deleuze argues that all actual things are themselves an expression of a process of intensification such that all the relations that concepts express are already relations of intensity $(1994$, p. 251). The dramatization of concepts, therefore, requires setting them into relationships with each other in ways that express the intensity of the relationships they already express; it is a way of determining the Idea that the concept expresses. As Deleuze puts it, 'intensity is the 
determinant in the process of actualization. It is intensity which dramatizes' (Deleuze, 1994, p. 245). Nonetheless, we must be careful with this account of the ontological claims underpinning the method of dramatization because it may give the impression that dramatization simply discovers the Ideas that determine concepts in the rather traditional sense that layers of conceptualization are excavated in order to unearth the pristine reality of the Idea itself. As we have stated throughout, however, the method of dramatization has a second, 'evental' dimension that must be appreciated. In the remainder of this section, we will specify why this second aspect is required and what it brings to light in terms of the ontological claims that sustain dramatization as method. This demands a further foray into Deleuze's metaphysics of difference.

If we accept that to dramatize is to express the intensive relations constitutive of concepts and if we accept that this is achieved by putting concepts into relationships of intensity with each other, then it makes sense to inquire more deeply into the nature of these intensive relations. In our view, there are four key ontological claims that must be explicated if the method of dramatization is to be sustained. (That said, this is not the place to engage in the justification of these ontological claims, at least not in the full sense that this would normally imply. With our aim of presenting dramatization as method, we must rest content with pointing the reader to the relevant primary sources where this work is done and the secondary commentaries that engage with the ontological arguments.) First, Deleuze argues that all relations of quantity and quality are conditioned by intensity: 'in short, there would no more be qualitative differences or differences in kind than there would be quantitative differences or differences of degree, if intensity were not capable of constituting the former in qualities and the later in extensity, even at the risk of appearing to extinguish itself in both' (Deleuze, 1994, p. 239: see Hughes, 2009, for an interesting discussion of how intensity cancels itself out). Second, he argues that intensive relations are relations of 'pure difference'; self-differing variations within things, so to speak, rather than the differences between things whose essence we think we already know. Deleuze argues throughout his work that intensive relations are not subsumable within models of difference that presume the pregiven identity of the related things. He argues that identity-oriented definitions of difference (that view difference as opposition or contradiction, for example) always compare things against a pre-established view of 'the same' and thereby nullify difference. A non-identity oriented model of difference is one that can account for difference without the 'return of the same'; what he calls, 'pure difference'. Summarizing rather dramatically, he concludes that in order to grasp the reality of pure difference we must view it as an intensive difference; a difference of intensity rather than a difference of extension (Deleuze, 1990; Deleuze, 1994). Third, he argues that intensive difference is always subject to a principle of indetermination. As noted above in the 
discussion of Deleuze's relation to Kant, indeterminacy is not something to be avoided in the Deleuzean metaphysical system. On the contrary, there is a necessity to recognizing it as a condition of that which differs from itself, of pure difference. Deleuze uses the example of lightning to explain these three features of his explication of this different kind of difference: ' $\ldots$ instead of something distinguished from something else, imagine something which distinguishes itself - and yet that from which it distinguishes itself does not distinguish itself from it. Lightning, for example, distinguishes itself from the black sky but must also trail it behind, as though it were distinguishing itself from that which does not distinguish itself from it' (Deleuze, 1994, p. 28). We experience the lightning flash as a moment of intensity before its illuminating quality and before we can quantify its luminescence. This intensity is not in opposition to the darkness from which it emerges (to say so would presume that darkness itself has no intensity) nor is it determinable vis-à-vis the intense nature of the darkness because that has its own intensity (it does not make sense to say that the flash of lightning is the same as 100,1000 and so on moments of darkness).

Lastly, for our purposes, as fundamentally indeterminate, relations of pure difference are an ideal but nonetheless real component of actual - determinable things. Of course, 'ideal' here refers to Deleuze's materialist understanding of the Idea and, as such, should not be taken to imply any sense of perfection. Nor are Ideas the 'property' of a unified subject: be it an individual person or a trans-historical spirit. An Idea, for Deleuze, is a distribution of differential relations indeterminate in themselves but nonetheless productive of efforts to determine them (as we saw in his account of aesthetic experience derived from Kant). An Idea, therefore, and as Deleuze is fond of saying, is not a set of concepts we employ to resolve a problem in our representation of the world, rather an Idea is a real problem that makes us think conceptually. It is real in that it resides outside of us as a provocation to thought; it is a problem to the extent that it is constituted as a system of differential relations that cannot (in principle) be determined once and for all. Ideas, we can say, are problems without any single solution. Borrowing the term from Bergson, Deleuze (1988) refers to the indeterminate yet real nature of Ideas as virtually implicated in every actual attempt to determine them through conceptualization. As such, Deleuze's ontological commitments lead him to argue that every determination of the real is conditioned by a virtual Idea of that reality. For example, every conceptualization of the elements of political reality is conditioned by an Idea of the political that is the problem that it expresses.

But why does the method of dramatization express this intrinsically problematic nature of the Idea while other methods do not reach the Ideal problem they seek? Characteristically, Deleuze's answer to this question can be found in the connection he establishes between the method of dramatization

492 (C) 2011 Macmillan Publishers Ltd. 1470-8914 Contemporary Political Theory Vol. 10, 4, 482-501 
and certain forms of question. In the defence of his Doctorat d'État, he puts it like this:

The Idea responds only to the call of certain questions ... . The question what is this? prematurely judges the Idea as simplicity of the essence; from then on, it is inevitable that the simple essence includes the inessential, and includes it in essence and thus contradicts itself ... [the Idea] can be determined only with the questions who? How? How much? Where and when? In which case? - forms that sketch the genuine spatiotemporal coordinates of the Idea. (Deleuze, 2004, pp. 95-96; see also Deleuze, 1994, p. 246)

Now we can answer the question of how we dramatize a concept; we ask questions such as 'how much of it is there?', 'how much do we want it?', 'do we want it here, this much in this context but that much in another context?', 'should we use this concept now, but not then or in the future?'. The point is that this takes us to the frontiers of the concept, its moments of intense crystallization such that we are able to access the differential relations that make up the Idea that it expresses - though only through this particular determination of the concept. But isn't there still something obscure in all this: for how do we get to the moment of intensification within the concept through which we can 'discover' the differential relations? Williams captures what is at stake:

An actual thing must change - become something different - in order to express something. Whereas, the expressed virtual thing does not change - only its relation to other virtual things, other intensities and Ideas change. This explains the conceptual innovations of Difference and Repetition. Deleuze has to introduce the concepts of multiplicities of pure differences and of envelopments of intensities to escape ways of thinking of change in terms of causal changes in parts that effect a whole. (Williams, 2003, p. 200)

Given the two-fold ontology of the virtual (yet real) intensities enveloped in all actual, extensive things, if we simply conceptualize things as they appear to us we will always miss that part of reality that conditions our experience of the thing itself. Yet, in order to access this other (virtual) part of the thing itself we must change that which is actually present. In doing so, we will be able to reveal the forces at work within things, but we will also have impacted upon those forces, at the level of the Ideal events that constitute them, and thereby changed the Idea itself that the concept expresses. To know the Idea behind the concept, therefore, is to change the relations within and between concepts so as 
express the system of the pure differential relations constitutive of the nonrepresentational Idea that conditions our determination of the concept. In political theory, dramatization as method requires that we stage new relations within and between the concepts that animate politics in order to express the indeterminate yet endlessly provocative nature of the Idea of the political. This complex set of relations can be set in motion when we forsake questions that look for the essence of the concepts that we use and instead ask questions about the force or power of concepts in particular circumstances; such as 'how do I play the "knight of faith", the "proletarian"?'; 'how useful is the concept of the state to contemporary political life?'; 'does rationality have any force when we think about human relationships?'; 'to what extent is justice applicable to the family?' and so on. The results of such questions, to the extent that they do not return to questions of essence, are always a provocation to political thought because they condition concepts that are (potentially, at least) expressive of the Idea of the political.

\section{Dramatization, Political Concepts and the Idea of the Political: An Example}

As with all methods, it is useful to see the method of dramatization at work in a practical context. Although we cannot hope to give a full sense of how this method can be applied (though we will offer some suggestions in the conclusion), we can present one example in which Deleuze and Guattari, as political philosophers, actually go about dramatizing a political concept; that is, how they employ the method of dramatization in order to express the Idea of the political. The example is developed from (some of) Deleuze and Guattari's statements about the concept of 'ideology' as they appear across Anti-Oedipus and $A$ Thousand Plateaus.

At the beginning of $A$ Thousand Plateaus Deleuze and Guattari categorically assert: 'there is no ideology and never has been' (Deleuze and Guattari, 1988, p. 4). What function does this dramatic claim or intervention perform? We argue in this section that this statement functions as an 'order-word' or, what Deleuze and Guattari would also call, 'slogan'. In A Thousand Plateaus, Deleuze and Guattari argue that any critical or political analysis of language must proceed on the basis that language operates through the issuing of slogans or order-words. That is to say, the function of order-words or slogans is 'co-extensive' with language itself (Deleuze and Guattari, 1988, p. 79). In this context, the writing practice in $A$ Thousand Plateaus embodies or dramatizes their critical analysis; it is a performative enactment of the critical method they deploy. They sloganize, and in so doing, philosophically and politically problematize what it means to speak of the concept of ideology. It is worth unpacking this claim a little more.

494 (C) 2011 Macmillan Publishers Ltd. 1470-8914 Contemporary Political Theory Vol. 10, 4, 482-501 
First, and as Jean-Jacques Lecercle (2002) points out, the slogan should always be understood in terms of the instantaneousness of its emission, perception and transmission. Rich in perlocutionary effect, the force of the slogan/ statement is dramatically exerted in a flash (Lecercle, 2002, p. 171). 'There is no ideology and never has been' is a rather dramatic, even audacious, statement given that it assumes its form against a background or a historical tendency to theorize language as ideology; say, for example, as the ideological or superstructural re-presentation of a more or less determined economic content. If Deleuze and Guattari's statement can be said to be rich in perlocutionary and dramatic effect, then this is not because it represents something familiar and easily communicable, but precisely because it forces a confusion upon readers who have acquired the habit of politicizing language in accordance with a particular notion of the ideological, one explicitly or even vaguely grounded in terms of the 'economic base', however subsequently or subtly defined (Deleuze and Guattari, 1988, p. 89).

This brings us to second characteristic of the slogan, what Deleuze and Guattari would call its 'power of forgetting'. For if the slogan is an instantaneous and dramatic flash, then its power and effect is particular to the context in which it operates. There is an implicit functionalism in this. Put simply: a slogan does not represent something, or mean something, as much as it functions by intervening 'here' or 'there', as Deleuze would say. A slogan is not a claim to transcendence or universality, so much as a singularly useful intervention that changes things. The 'power of forgetting' in the slogan is a singular power that allows only for a certain movement or change in things, that allows us to forget in order to move on, 'permitting one to feel absolved' of the slogans 'one has followed and abandoned' and 'to welcome new ones' (Deleuze and Guattari, 1988, p. 84).

It should come as no surprise then that Deleuze and Guattari in a later passage of $A$ Thousand Plateaus entertain the possibility of revamping or dramatizing the concept of ideology anew. 'The only way to ... revamp the theory of ideology [is] by saying that expressions and statements intervene directly in productivity, in the form of a production of meaning or sign-value' (Deleuze and Guattari, 1988, p. 89). By intervening directly in the production of meaning or sign-value, we could say that language or the statement/slogan has a certain ideological power or capacity to produce meaning, to dramatically force meaning in this way or that. Thereby a critique of ideology would not focus on the supposedly superstructural or epiphenomenal expression of any reflected or represented economic-social content, but would locate itself at the very heart of meaning-production itself. Deleuze and Guattari do indeed perform this kind of ideology critique when they critically engage with psychoanalysis in Anti-Oedipus (Porter, 2006, pp. 98-100). The basic point is this: psychoanalysis is ideological to the extent that it produces meaning as 
desire expressed as 'lack'; to the degree that it fabricates or constructs 'lack' in or through the social relations of the contemporary polity. Meaning as 'lack' is anchored in the process of production quite explicitly, for Deleuze and Guattari, precisely because it structures desire in accordance with the wants, needs or values of the dominant class in the contemporary market economy. Or as they explicitly put it: 'The deliberate creation of lack as a function of market economy is the art of a dominant class' (Deleuze and Guattari, 1984, p. 28).

To sloganize Deleuze-Guattari style is to immediately problematize and critique the idea that language finds its primary function in representation. A word like ideology cannot simply be represented by way of a meaning that remains unproblematic. Rather it is pragmatically connected to a form of language-use that continually plugs it into various conjunctures/bodies. This is why there is no necessary contradiction in Deleuze and Guattari seemingly dismissing the efficacy of 'ideology' as a critical tool ('There is no ideology and never has been') while also engaging in an ideology-critique of psychoanalysis (where 'lack' is seen 'as a function of market economy' and 'the art of a dominant class'). Of course, we may be tempted to say that Deleuze and Guattari are simply rejecting one concept of ideology (that is, the model that understands ideology to be a reflection of an always-already given economicsocial content) and suggesting another (where ideology directly intervenes in meaning-production). But this already assumes too much by overlooking the important extent to which the pragmatic use of language, as Deleuze and Guattari provocatively say, 'insinuates itself into everything' (Deleuze and Guattari, 1988, p. 78). We assume the word is subject to a law of identity, say semantically, and rather casually forget that, pragmatically speaking, it is subject to continual variation every time it performs its meaning-production function. Put simply, the word or concept of 'ideology' continually varies or is constantly differentiated across, and even at times within, the actual texts of Anti-Oedipus and $A$ Thousand Plateaus.

Coming back, then, to consider how the method of dramatization may work itself out in actual or practical contexts, we can begin to see how Deleuze and Guattari's differing pragmatic interventions or statements on ideology in Anti-Oedipus and $A$ Thousand Plateaus connect back the virtual-actual logic developed by Deleuze in Difference and Repetition. Clearly we have the dramatization of a political concept (ideology) within actual conditions (the texts of Anti-Oedipus and $A$ Thousand Plateaus). But, how, we still need to ask, does this dramatization reveal the virtual relations that express the Idea of the political? In this actual and practical context ('here' at this point in Anti-Oedipus and then 'there' at that point $A$ Thousand Plateaus) we have a political concept caught up in a form of practical use, movement or set of relations (ideology as this, and then that ...) that is, in the end, 'virtual', or which already has the 'virtual' potential for continual differentiation. In principle, we can perpetually

496 (C) 2011 Macmillan Publishers Ltd. 1470-8914 Contemporary Political Theory Vol. 10, 4, 482-501 
engage in the linguistic, literary or textual dramatizations of the political concepts like 'ideology' precisely because language has, what Deleuze and Guattari would call, a 'virtual' potential for 'continuous variation'. 'It is possible', they say, 'to take any linguistic variable and place it in variation following a necessarily virtual continuous line' (Deleuze and Guattari, 1988, p. 99). And, in this sense, we can think of such potential virtual movement as revealing or, better still, expressing the Idea of the political as such, where the 'Idea of the political' precisely becomes at one and the same time the virtual potential for continual variation or differentiation of political concepts such as 'ideology'.

\section{Conclusion}

Although in need of further work in the comparative study of methodologies, it has been our aim to point towards the possibility of treating dramatization as a viable alternative to standard methodological practice in political theory; an alternative that could sit alongside other critically oriented approaches in the discipline. ${ }^{6}$ By way of conclusion, we shall speculate briefly about the potential for dramatization to be used as a way of engaging with the texts and the tasks of political philosophy.

In terms of the discourse of political philosophy, or the history of Western political thought in particular, Deleuze and Guattari's method of dramatization can undoubtedly function as a rather interesting provocation. For if we were to take Deleuze and Guattari's method of dramatization seriously this would necessitate an interesting shift in how we situate ourselves on this terrain. Put simply, we could think of the history of Western political thought itself as a drama, the movements and innovations in which we can track with an eye to the modes of dramatization employed. This is not simply about saying that truly innovative political philosophers engage in the dramatization of concepts (though they undoubtedly do that), but that these dramatizations are precisely what gives their concepts their force, quality and vitality because they are at once at invitation to participate in, play with and discover these concepts. So, a truly innovative and influential political philosopher like Rawls (1972), for instance, does not simply confront us with concepts that are vivid, striking, provocative and powerful (though he undoubtedly does that), he invites us to participate in the drama he is directing and to discover concepts through this drama. A Theory of Justice is a dramatic script that we readers can pick up and play. Think, most obviously perhaps, of the role of the contractor, in the 'original position' behind the 'veil of ignorance', who must construct the principles of justice. Our view is that those critics of Rawls who would challenge the status and form of the thought-experiment he directs and asks us to perform, crucially miss the point that he is precisely provoking us to play 
with the thought-experiment and to discover the concepts that follow from it (for instance, the 'difference principle', 'fairness' and so on), and to be open to the force, power and effect that this play may have on us as reader-performers.

Regarding the tasks of political theory we can say, first of all, that dramatization impacts upon our sense as political theorists of what is involved in the process of conceptualization itself. The practical and critical nature of this process is, according to Deleuze, based on a set of ontological assumptions that require us to think of it as a necessarily artistic intervention in the world. The artistry resides in forging concepts that intensify our political relations to the point of constituting them anew. It is an artistry that demands of political theorists that they are always looking to ask the better question; the question that brings out the intense relationality within and between the concepts of our disciplinary discourses. Thinking of method in this way, as the art of conceptualization, may bring Deleuzean political theory into productive dialogue with the debates set in motion by Gallie's (1956) notion of 'essentially contested concepts'. What it would add to these debates, we suggest, is a rigorous ontological framework that positions the debate about essential contestability on a terrain before the problem of evaluation.

Of course, and this is our final point, the dramatization of political concepts is not confined to engaging with the texts, concepts and conceptualization of Western political thought. At once both a profound and banal assertion, to be sure, but it is clear to us that the dramatization of political concepts is all around us, as densely woven into the fabric of ordinary everyday experiences. Clearly, this means that we should be critically sensitive to the ways in which political concepts emerge from a range of places, and how they come to us in a range of forms or genre. Put more strongly still, we believe that any political theory that claims to be alive to the problem of dramatization must necessarily look outside the confines of the discipline in order to discover or come to know how the political concepts that work on us and shape us are dramatized, how they are given their force, quality and vitality. For example (and as we are both either former or current citizens of Belfast), we could write a political theory of contemporary Belfast that looks at the ways in which the city has become normalized and governmentalized as a supposedly 'post-conflict' city, and we could write about how that this 'normalization' of Belfast has opened the door to a new type of politics where agents of normalization (for instance, influential property developers) have become 'moral' agents whose motivations are never questioned and whose actions are never subject to any public criticism or scrutiny. We could write this political theory, but for us nothing more forcefully dramatizes the concept of Belfast as a 'post-conflict' city than its developing built environment. Rather than writing this political theory, or in order to write it better, with more forceful purpose, vitality and resonant power, it may be well better for us first to take a walk around and orient ourselves in Belfast

498 (C) 2011 Macmillan Publishers Ltd. 1470-8914 Contemporary Political Theory Vol. 10, 4, 482-501 
to see how the notion of the 'post-conflict' city is being conceptualized within the shifting spaces of urban and property development. As Deleuze and Guattari were often fond of saying, going out for a stroll and experiencing a little wind from the outside can be productive, and we think political theorists like us (and, dare we say it, like you too) need to get out more.

\section{Acknowledgements}

We thank the editors and two anonymous referees of this journal for their constructive comments on an earlier draft of this article.

\section{Notes}

1 Addressing the relationship between Deleuze and political theory through the question of method raises two important interpretive problems. On the one hand, there is the problem of where to situate dramatization in the collective output of Deleuze and Guattari. On the other hand, there is the problem of privileging the idea of method in relation to their work. We will not dwell extensively on either problem but we do believe that it is important to clear the ground in relation to these matters so that the discussion of dramatization as method can begin in earnest. First, there is no doubt that dramatization as method originates in the writings of Deleuze rather than Guattari. Indeed, one can trace this method through Deleuze's work without the need for separate discussion of Guattari's individually authored texts. That said, one must include within Deleuze's body of work the collaborations with Guattari (Deleuze and Guattari, 1984, 1986, 1988, 1994). With these issues in mind, we refer the reader to the important discussions of the theoretical and interpretive complexities raised by Deleuze and Guattari's authorial practices that can be found in Genosko (2002) and Stivale (1998).

Second, 'dramatization as method' has not, with a few exceptions (for example, Boundas and Olkowski, 1994), been fore grounded in interpretations of Deleuze and Guattari's oeuvre. In part, this may be the result of the complicated authorial background just mentioned but it may also be because there is concern about locating 'a method' in Deleuze and Guattari; at least for those interpreters who see all methodologies as overburdened with presuppositions incompatible with a philosophy of difference. It is our view, on the contrary, that the method of dramatization not only occupies a pivotal place in Deleuze and Guattari's philosophical system (even though it appears to have a relatively short-lived existence within their work), but it is also a method that is entirely consistent with the difference-oriented philosophy they construct. Moreover, we take it that there is nothing about method, per se, that disqualifies us from privileging it in our presentation below.

2 We will use 'Ideas', capital I, in a technical Deleuzean sense, but retain 'ideas', without capitalization, for other understandings of the term.

3 Although we cannot sustain this claim in this article, we venture that there is an interesting history of political theory to be written that focuses on the methodological importance of comedy in the construction of political concepts.

4 We return to the importance of the 'form of the question' below.

5 While the process of crystallization serves as an example in this discussion, it is important to stress that the individuation it describes is a general ontological principle for Deleuze and, as 
such, he sees no fundamental difference between the individuation of particular crystals and the individuation of concepts in thought. See Toscano (2006) for an excellent account of individuation in Simondon and Deleuze.

6 By 'standard methodological practice' we have in mind, on the one hand, various approaches to the interpretation of texts (be they classic texts in political theory or documents drawn from the world of everyday politics) and, on the other hand, the normative approaches that make up most of what we call political theory. By critically oriented methodologies we have in mind some feminist methodological practice, critical discourse analysis and varieties of Marxism, to name the most prominent. For good overviews of the current state of the methodological mainstream and counter-currents in political theory see Marsh and Stoker (2010) and Leopold and Stears (2008).

\section{References}

Bergson, H. (2004) Laughter: An Essay on the Meaning of the Comic. Whitefish, Montana: Kessinger Publishing.

Boundas, C.V. and Olkowski, D. (eds.) (1994) Editors' introduction. Gilles Deleuze and the Theater of Philosophy. London: Routledge.

Debrix, F. and Weber, C. (eds.) (2003) Rituals of Mediation: International Politics and Social Meaning. Minneapolis, MN: Minnesota University Press.

Deleuze, G. (1983) Nietzsche and Philosophy. London: Athlone Press.

Deleuze, G. (1984) Kant's Critical Philosophy: The Doctrine of the Faculties. Minneapolis, MN: University of Minnesota Press.

Deleuze, G. (1988) Bergsonism. New York: Zone Books.

Deleuze, G. (1989) Cinema 2: The Time Image. Minneapolis, MN: University of Minnesota Press.

Deleuze, G. (1990) The Logic of Sense. New York: Columbia University Press.

Deleuze, G. (1991) Empiricism and Subjectivity: An Essay on Hume's Theory of Human Nature. New York: Columbia University Press.

Deleuze, G. (1994) Difference and Repetition. New York: Columbia University Press.

Deleuze, G. (2004) Desert Islands and Other Texts 1953-1974. Los Angeles, CA: Semiotext(e).

Deleuze, G. and Guattari, F. (1984) Anti-Oedipus: Capitalism and Schizophrenia. New York: Viking Press.

Deleuze, G. and Guattari, F. (1986) Kafka: Toward a Minor Literature. Minneapolis, MN: University of Minnesota Press.

Deleuze, G. and Guattari, F. (1988) A Thousand Plateaus: Capitalism and Schizophrenia. Minneapolis, MN: University of Minnesota Press.

Deleuze, G. and Guattari, F. (1994) What is Philosophy? London: Verso.

Finlayson, A. and Frazer, E. (2009) Theatrical political thought: Shakespeare and the staging of civic experience. Challenges for Democracy in a Global Era, Proceedings of the 59th PSA Conference; 7-9 April 2009, Manchester, UK, http://www.psa.ac.uk/journals/pdf/5/2009/ Finlayson.pdf.

Gallie, W.B. (1956) Essentially contested concepts. Proceedings of the Aristotelian Society 56: $167-198$.

Genosko, G. (2002) Félix Guattari: An Aberrant Introduction. London: Continuum.

Grosz, E (2008) Chaos, Territory, Art: Deleuze and the Framing of the Earth. New York: Columbia University Press.

Hayden, P. (1995) From relations to practice in the empiricism of Gilles Deleuze. Man and World 28: 283-302.

500 (C) 2011 Macmillan Publishers Ltd. 1470-8914 Contemporary Political Theory Vol. 10, 4, 482-501 
Hobbes, T. (1968) Leviathan. In: C.B. Macpherson (ed.), London: Penguin. Hughes, J. (2009) Deleuze's Difference and Repetition. London: Continuum.

Kant, I. (1952) The Critique of Judgement. Oxford: Clarendon Press.

Kerslake, C. (2002) The vertigo of philosophy: Deleuze and the problem of immanence. Radical Philosophy 113: 10-23.

Kerslake, C. (2009) Immanence and the Vertigo of Philosophy: From Kant to Deleuze. Edinburgh, UK: Edinburgh University Press.

Lecercle, J.J. (2002) Deleuze and Language. Basingstoke, UK: Palgrave-Macmillan.

Leopold, D. and Stears, M. (eds.) (2008) Political Theory: Methods and Approaches. Oxford: Oxford University Press.

Lisle, D. (2009) The 'potential mobilities' of photography. Media/Culture 12(1), http://journal .media-culture.org.au/index.php/mcjournal/article/viewArticle/125.

Marsh, D. and Stoker, G. (eds.) (2010) Theory and Methods in Political Science, 3rd edn. Basingstoke, UK: Palgrave Macmillan.

McMahon, M. (2009) Immanuel Kant. In: G. Jones and R. Roffe (eds.), Deleuze's Philosophical Lineage. Edinburgh, UK: Edinburgh University Press, pp. 87-103.

Pappas, N. (2003) Plato and the Republic, 2nd edn. London and New York: Routledge.

Porter, R. (2006) Ideology: Contemporary Social, Political and Cultural Theory. Cardiff, UK: University of Wales Press.

Rancière, J. (2004) The Politics of Aesthetics: The Distribution of the Sensible. London: Continuum.

Rawls, J. (1972) A Theory of Justice. Oxford: Oxford University Press.

Shapiro, M.J. (1999) Cinematic Political Thought: Narrating Race, Nation and Gender. Edinburgh, UK: Edinburgh University Press.

Skinner, Q. (2008) Hobbes and Republican Liberty. Cambridge: Cambridge University Press.

Smith, D. (2006) Deleuze, Kant and the theory of immanent ideas. In: C.V. Boundas (ed.), Deleuze and Philosophy. Edinburgh, UK: Edinburgh University Press, pp. 43-61.

Stivale, C. (1998) The Two-Fold Thought of Deleuze and Guattari: Intersections and Animations. New York: The Guildford Press.

Toscano, A. (2006) The Theatre of Production: Philosophy and Individuation between Kant and Deleuze. Basingstoke, UK: Palgrave Macmillan.

Virilio, P. (2003) Art and Fear. London: Continuum.

Williams, J. (2003) Gilles Deleuze's Difference and Repetition: A Critical Introduction and Guide. Edinburgh, UK: Edinburgh University Press. 